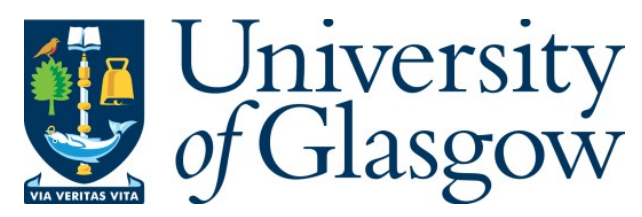

Meek, J. (2016) Masculinity, Class and Same-Sex Desire in Industrial England, 1895-1957. By Helen Smith. Twentieth Century British History, (doi:10.1093/tcbh/hww035).

There may be differences between this version and the published version. You are advised to consult the publisher's version if you wish to cite from it.

http://eprints.gla.ac.uk/122921/

Deposited on: 22 September 2016

Enlighten - Research publications by members of the University of Glasgow http://eprints.gla.ac.uk 


\title{
Masculinity, Class and Same-Sex Desire in Industrial England, 1895-1957. By Helen Smith
}

\author{
Masculinity, Class and Same-Sex Desire in Industrial England, 1895-1957. By Helen Smith. \\ Palgrave Macmillan, Basingstoke, 2015. ix + 244 pp. ISBN 978-1-137-47098-0, £63.
}

\author{
Jeffrey Meek, University of Glasgow
}

The experiences of male homosexuals in Great Britain during the first half of the twentieth century have attracted considerable scholarship, yet much of this has been dominated by studies relating to larger metropoles. A high standard has been set for research into same-sex desire, queer experiences and networks, Matt Houlbrook's Queer London being the most notable example. Yet, Helen Smith has sought to add more layers to our understandings by examining same-sex desire in diverse working-class communities throughout industrial England. By doing so, she breaks new ground in the exploration of national and regional experiences of male homosexuality and considers how social class, masculinity, environment and visibility impacted personal, social and legal attitudes.

Using a combination of criminal trials, personal memoirs, press coverage and oral history excerpts, this book examines same-sex desire during the period 1895-1957. Such research not only adds geographical depth to our knowledge but also highlights how social and legal attitudes to same-sex desire were negotiated locally and were influenced and shaped by specific discourses of sexuality framed by class, environment and experience. What appears evident from Smith's research and analysis is that men who conducted same-sex relationships away from the public realm in industrial England were relatively safe from police intrusion, and same-sex relationships between men in Northern working-class communities fell within acceptable boundaries of ordinary life. Largely absent in these communities was the salacious reporting and prurient interests in the sexual lives of working-class men sometimes evident in the capital during the same period. The police, as Smith details, were not generally in the habit of targeting homosexuals but did participate in the regulation of public decency. What is evident is that the north saw itself as quite distinct from London. Smith makes this point consistently and evidences this in the treatment of homosexuality by the northern press and police, using the coverage of the Oscar Wilde trials as evidence that northern appetites for salaciousness appeared considerably lighter than in London. There is little evidence that any concerted campaigns against homosexuality were undertaken by the varied police forces across the industrial north, which also demonstrated that legal authorities there were not influenced by any campaigns undertaken in the capital. Uncertainty regarding how to treat homosexual offences was also evident amongst the police in the north during the interwar period, which Smith suggests could have been the result of either indifference or tolerance towards same-sex desire (p. 56).

This idea of tolerance is again highlighted when the book discusses Edward Carpenter's experiences in Sheffield, a place where Carpenter claimed attitudes towards same-sex desire were not clouded by the restrictive views of homosexuality evident elsewhere. The vivid discussions of Carpenter's relationships with George Hukin and George Merrill again underline that in the industrial north same-sex relationships between men were not 
uncommon and were not generally viewed as pernicious but pointed to the fluid nature of working-class male sexualities (pp. 70-81).

Smith highlights how inconsistencies in the sentencing of men convicted of 'homosexual offences' suggested a rather muddled appreciation of same-sex desire by the authorities. Further, the lack of high-profile cases within larger urban communities points to a much more privatized experience of same-sex relationships amongst working-class men in the industrial north of England. More sympathetic attitudes appear to have survived beyond the interwar period, even though more restrictive concepts of homosexuality were being more widely promoted, particularly in London. Everyday male intimacies began to be more problematic after the publication of the Wolfenden Report in 1957, which introduced restrictive concepts of the male homosexual and problematized once accepted homosocial interactions, which occasionally led to more intimate connections between male industrial workers. As Smith details, such behaviour could no longer be deemed innocent, but became an indicator of sexual preference (p. 190).

Smith argues that visible urban homosexual subcultures did not emerge until the 1950s, Manchester being a prime example. Manchester at this time displayed many of the subcultural indicators already evident in London: for example, camp names, make-up, prostitution and queer venues (p. 154). This new visibility was linked to mannerisms, speech, dress and sexual behaviours and appeared to be a more pressing threat to social order. This homosexual 'identity' was a much more problematic concept for the men and their families, as Smith details in the case of 'Cliff': a young, working-class man whose behaviour was tolerated by his family until he made the decision to come out as homosexual (p. 193).

However, Smith's research demonstrates that working-class men in industrial England, for the most part, were able to enjoy flexible sexual lives, where enjoyment of same-sex intimacies did not problematize their masculine identities. This is especially evident in the period between 1895 and the publication of the Wolfenden Report. Even when private intimacies spilled into public space, a criminal prosecution or suspicion of homosexual inclinations did not generally influence attitudes towards the offender. As Smith argues, this had much to do with concepts of masculinity, their sense of class and the region in which they lived. The book offers significant depth and engagement on the issues of sexuality, class and masculinity in industrial England between 1895 and 1957, and although the discussion on Ferdynand Zweig's work feels a little sandwiched in, this is a rich, accessible and important contribution to our understanding of same-sex desire, class and masculinity in Britain. 